\title{
Perceived Body Image in Psychology Students from Yucatán, Mexico
}

\author{
Guadalupe Simanga Ivett Robles Hernández, M.C. \\ Ricardo Gumaro Molina Jacquez, M.C. \\ Omar Benjamín Solís, Dr. \\ María Del Carmen Zueck Enríquez, Dr. \\ Humberto Blanco Vega, Dr. \\ Martín Alonso González Hernández, M.P.A. \\ Fernando Mondaca Fernández, Dr. \\ Carolina Jiménez Lira, Dr.
}

Facultad de Ciencias de la Cultura Física,

Universidad Autónoma de Chihuahua, México

Doi:10.19044/esj.2020.v16n14p27～URL:http://dx.doi.org/10.19044/esj.2020.v16n14p27

\begin{abstract}
Body image is an important psychological component related to current health issues such as eating disorders. It is also related to social, peer, and family pressure, by which men and women are affected to different degrees. Thus, the goal of the present research was to compare the perceived body image profiles in Mexican psychology students. The total sample consisted of 271 students; 139 women and 132 men from the Autonomous University of Yucatán, ages ranged between 17 and 28 years. The approach adopted in this research was quantitative with a descriptive survey like design. The results from the multivariate analyses of variance followed up by univariate analyses of variance, show that men report a better perceived body image than women on the factors behaviors oriented towards maintaining the physical shape $(\mathrm{F}=317.008, \mathrm{p}<.001)$ and care of physical aspect $(\mathrm{F}=19.939$, $p<.001)$; and no significant differences on the factors of subjective importance of corporality and self-assessed physical attractiveness. These results show that in general men, in comparison to women show lower levels of dissatisfaction with their body image. Regardless, it is necessary that more research on the matter be developed given that the topic transcends the scope of the present research.
\end{abstract}

Keywords: Body image, gender, attitude, self-perceptions 


\section{Introduction}

The concept of beauty, until the early 20th century included the rounded shapes of a life of well-being and abundance. Today this has changed, slender bodies are being promoted for women and robust bodies for men. Consequently, body image has become a problematic aspect in the population, particularly among women (Brown \& Slaughter, 2011; Ochner, Gray \& Brickner, 2009; Poulisis, 2011).

Body image is a theoretical construct that is widely used in psychology and other health sciences. The concept is crucial for explaining some fundamental aspects of personality, such as self-esteem or self-concept, as well as eating disorders. Body image changes throughout a person's life, although it maintains a strong connection to childhood and the teenage years (Contreras, Gil, García, Fernández \& Pastor, 2012).

Self-image refers to the mental representation, impregnated with attitudes and assessments that the person makes about his or her own body. This mental representation corresponds to a changing and experiential process throughout a person's lifespan (Raich, 2000; Toro, 2013). In adulthood, body image tends to evolve slowly along with changes that are characteristic of the human being and/or events that suppose important changes in the physical aspect, that may be either natural (Abouzari-Gazafroodi, Najafi, Kazemnejad, Rahnama \& Montazeri, 2015; Watson, Fuller-Tyszkiewicz, Broadbent \& Skouteris, 2015) or traumatic.

The elaboration of an adequate self-perception is essential to organize behaviors that are necessary to adaptation between the individual and his or her environment (Pastor, 2007). Thus, dissatisfaction emerges from the comparison between the perceived body shape (whether realistic or not) and the ideals imposed by cultural standards (Cash \& Smolak, 2012; Le Breton, 2002; Platas, Gómez-Peresmitré \& León, 2014; Raich, 2000).

Likewise, current society is focused on overassessment of body image and beauty. These factors impact both behavior and thought in the most vulnerable population. This pressure from the social environment originates, in the youngest members of our society, risk behaviors for physical and mental health (Durán, Díaz, Record, Cordón, Encina \& Araya, 2014).

To make matters worse, if a person is thin, there are reasons to make a positive assessment (especially for women); however, those who differ from the slender model suffer body dissatisfaction and may suffer low self-esteem, as well as worse self-concept, anxiety and depression (Rodríguez-Fernández, Axpe \& Goñi, 2015; Solano-Pinto \& Cano-Vindel, 2012).

It is convenient then to point out the need to assess not only attitudes towards body image, but also, the strength of those attitudes. This aspect is not only relevant to the general population, but also, predictably, for people diagnosed with eating disorders (Gasco, Briñol \& Horcajo, 2010). 
Most of the scales proposed to assess body image have been designed in the Anglo-Saxon, and European context. However, it is necessary to take into account the specific cultural characteristics of a population and their relation to body image (Rodriguez, Oudhof, Gonzalez-Arratia \& UnikelSantoncini, 2010). For example, in a study about body image in psychology students, using an instrument designed by Solano-Pinto and Cano-Vindel (2010), the cognitive-emotional components were found to be grouped, broken down in turn into emotional discomfort, fear of gaining weight and change planning factors as well as the perceptual and behavioral factors, in which feelings of low self-worth, sadness and irritability were associated with the body figure (Solís, Blanco, Solano-Pinto \& Gastelum, 2017).

With respect to research on body image and gender, the results of a study with female participants sustain the need to deepen the knowledge of attitudes and eating disorders in adult women, given that it is at this stage in life when recurrence to extreme weight control methods may signify a risk factor for their health (Álvarez-Rayón, Franco-Paredes, López-Aguilar, Mancilla-Díaz \& Vázquez-Arévalo, 2009).

Some authors question whether these eating behaviors constitute a continuum (López-Guimera \& Sánchez-Carracedo, 2010), in both men and women, while other authors signal body dissatisfaction as a risk factor for the development of eating disorders and obesity (Marco, Perpiñá \& Botella, 2014; Wilksch, Paxton, Byrne, Austin, McLean, Thompson, Dorairaj \& Wade, 2015).

However, the relationship between body image disorders and physical activity is apparently paradoxical in nature (Pastor, 2007). In many cases, it is helpful in improving body image, but eating disorders are most frequently present in sports where weight control is important, such as rhythmic gymnastics, artistic skating or resistance sports. Confirming this, body image has been found to be strongly dependent on the type of sport that is practiced. The younger people who practice sports and individual fitness activities, are the most vulnerable population who possess the worse body image, (González-Montero, André, García-Petuya, López-Ejeda, Mora, \& Marrodán, 2010; Requena-Pérez, Martín-Cuadrado \& Lago-Marín, 2015; VaqueroCristóbal, Alacid, Muyor \& López-Miñarro, 2013).

On the other hand, most studies show that women have higher body image dissatisfaction (Salazar, 2008; Trejo, Castro, Facio, Mollinedo \& Valez, 2010), and that they tend to distort it more than men (González-Montero et al., 2010), either on self-assessment or body composition measures, not all studies have found this relation (Gómez-Mármol, Sánchez-Alcaraz \& MahederoNavarrete, 2013; Gómez-Peresmitré \& Pineda, 2014). The encountered results show that the socialization process, from the biological, social and cultural 
perspective, define what men and women should be, as well as the how their body shapes should differ, (Gómez-Peresmitré, 2014).

Therefore, the aim of the present research was to assess the attitudinal aspects of body image in female and male undergraduate psychology students from the Autonomous University of Yucatán. For the present study, we used the MBSRQ questionnaire which was validated in Spain (Botella, Ribas, \& Ruiz, 2009). Our goal was to analyze whether perceived body image would differ between men and women, specifically on the following factors: a) subjective importance of corporality, b) behaviors oriented towards maintaining physical shape, c) self-assessed physical attractiveness, and d) care of physical aspect, differ between men and women. Based on prior research (i.e., Salazar, 2008; Trejo, et al., 2010) we hypothesized that female psychology students from Yucatán, México, would report higher perceived body image dissatisfaction than male students.

\section{Method}

\section{Participants}

A total of 271 university students from Mérida Yucatán, Mexico participated in the present study, 139 women and 132 men. Participant age ranged between 17 and 28 years, with a mean of $20.59 \pm 1.82$ years for women and a mean of $21.15 \pm 1.18$ years for men.

The sample was obtained by convenience sampling, trying to include students from the different semesters from the undergraduate Psychology Program at the Faculty of Psychology at the Autonomous University of Yucatán.

\section{Procedure}

Undergraduate psychology students from the Faculty of Psychology at the Autonomous University of Yucatán (México) were invited to participate in the study. Those who agreed to participate signed the informed consent form. The previously described instrument was then completed in a single approximately 40-minute session, using a personal computer in the computer labs at the Faculty of Psychology.

At the beginning of the session, a brief introduction on the importance of the research and how to access the instrument was given. Students were asked for maximum honesty and students were assured confidentiality of the collected data. The instructions on how to answer were found on the first screens before the first questionnaire item. At the end of the session, students were thanked for their participation. Once the instrument was completed, data were downloaded by means of the module generator from the scale results editor version 2.0 (Blanco, Ornelas, Tristán, Cocca, Mayorga-Vega, LópezWalle, \& Viciana, 2013). 


\section{Instrument}

Spanish Version of Botella et al., (2009) of the Multidimensional Body Self Relations Questionnaire (MBSRQ) (Brown, Cash, \& Mikulka, 1990), is composed of 45 items grouped into 4 dimensions or subscales: subjective importance of corporality (SIC), behaviors oriented towards maintaining the physical shape (BMPH), self-assessed physical attractiveness (SAPA) and physical aspect care (PAC). According to Botella et al., (2009) the MBSRQ in its Spanish version has good internal consistency, good temporal stability, and validity (SIC factor obtained Cronbach's Alpha of .940, the BMPH factor of .807 , the SAPA factor of .8042 and the PAC factor .709).

This study used the Spanish version of the MBSRQ adapted by Blanco (2016) who, based upon his study with university students made two adaptations to the Botella et al., (2009) version:

The first adaptation, on the original instrument a scale of 1 to 5 was used, in the adapted version by Blanco (2016), participants choose between 6 possible responses: completely disagree (0), disagree (1), partially disagree (2), partially agree (3), agree (4) and completely agree (5).

The second adaptation consisted in applying the instrument by means of a computer (Figure 1); this was done in order to allow data storage without the previous coding stages, faster, and with more precision.

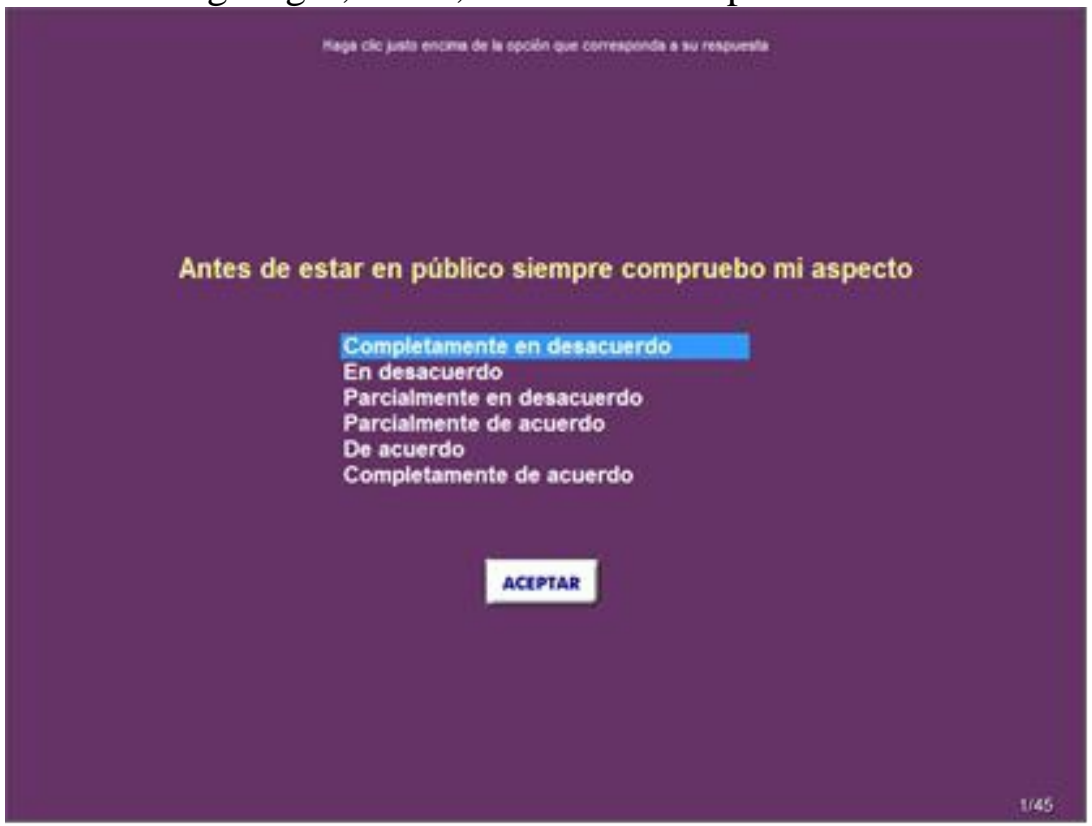

Figure 1. Example of the questionnaire item response 


\section{Design}

Regarding the study design, a quantitative approach was used with a descriptive cross-sectional survey type (Hernández, Fernández y Baptista, 2014). The independent variable was gender and the dependent variables were the mean of the scores obtained on the four factors or subscales of the MBSRQ: subjective importance of corporality, behaviors oriented to maintaining the physical shape, self-assessed physical attractiveness and care of physical aspect.

\section{Results}

\section{Data Analyses}

Descriptive data analyses were carried out for all dependent variables. After ensuring that the data met all the assumptions for parametric statistical analyses, a multivariate analyses of variance (MANOVA), followed up by univariate analyses of variance (ANOVA), to examine the differences between men and women regarding perceived body image on the factors subjective importance of corporality, behaviors oriented towards maintaining physical shape, self-assessed physical attractiveness and care of physical aspect, the effect size was estimated using et squared $\left(\eta^{2}\right)$. All statistical analyses were performed using SPSS version 21.0. The statistical significance level was set at $p=.05$.

\section{Results from Analyses}

Table 1 shows means and standard deviations for perceived body image on the four factors of the MBSRQ, as well as the results from the MANOVA and the subsequent ANOVAs. The results of the MANOVA showed overall differences by gender on the perceived body image scores (Wilks' $\lambda=.893 ; p<.001 ; \eta^{2}=.107$ ). The results from the ANOVAs showed that men report a better perceived body image than women on two of the four factors: behaviors oriented towards maintaining physical shape $(F=317.008$, $p<.001)$ and care of physical aspect $(F=19.939, p<.001)$. 
Table 1. Results from the MANOVA and follow-up ANOVAs for the differences in perceived body image by gender

\begin{tabular}{|c|c|c|c|c|c|}
\hline & $\begin{array}{c}\text { Women } \\
(n=139)\end{array}$ & $\begin{array}{c}\text { Men } \\
(n=132)\end{array}$ & $\mathrm{F}$ & $\mathrm{p}$ & $\eta^{2}$ \\
\hline MANOVA & & & 7.948 & $<.001$ & .107 \\
\hline $\begin{array}{l}\text { Subjective } \\
\text { importance of } \\
\text { corporality } \\
(\alpha=.708)\end{array}$ & $2.80(0.03)$ & $2.79(0.03)$ & 0.008 & $>.05$ & $<.001$ \\
\hline $\begin{array}{l}\text { Behaviors oriented to } \\
\text { maintaining physical } \\
\text { shape } \\
(\alpha=.862)\end{array}$ & $2.30(0.08)$ & $2.77(0.08)$ & 15.472 & $<.001$ & .058 \\
\hline $\begin{array}{l}\text { Self assessed } \\
\text { physical } \\
\text { attractiveness } \\
(\alpha=.789)\end{array}$ & $3.08(0.07)$ & $3.03(0.08)$ & 0.145 & $>.05$ & $<.001$ \\
\hline $\begin{array}{l}\text { Care of physical } \\
\text { aspect } \\
(\alpha=.701)\end{array}$ & $3.32(0.06)$ & $3.10(0.06)$ & 3.307 & $<.05$ & .023 \\
\hline
\end{tabular}

\section{Conclusion}

With regards to our hypothesis, that women would report greater body dissatisfaction, our results show that, in effect, women report less conformity with their body image. Our findings are consistent with previous studies that assert that women, in comparison to men who were same-aged and with a similar level of study, frequently wish to be slimmer or lose weight, whether it is necessary or not (Acosta, Llopis, Gómez-Peresmitré \& Pineda, 2005; Muñoz, Zueck, Blanco, Chávez \& Jasso, 2014) and they appear less satisfied with their body image (Mercado, 2008; Muñoz et al., 2014).

The obtained results are consistent with the possibility that, for our sample of undergraduates from the University of Yucatán, young women can be vulnerable to socio-cultural pressure that promotes an unrealistic beauty standard and impacts body image; transmitted through the media, family members or peers, as proposed by Englera, Crowtherb, Daltonb y Sanftner (2006), Rodriguez et al. (2010) and Jáuregui \& Bolaños (2010). However, further research is necessary to address the issue of the association between socio-cultural pressure and body image.

In addition, the differences encountered between men and women with respect to their perceived body image suggest that when designing any type of intervention that has the goal of improving body image the variable gender must be considered; however, it is important that more research be conducted 
because the topic transcends the scope of the present research. We underline the importance of carrying out more research on the matter in our country.

Finally, at least two limitations are present in this study. The first is that participants were all students, which poses a threat to the generalizability of results. Enlarging our sample (including young adults who are not enrolled in school) is an area for future work. The second limitation comes from the measurement instrument, which is a self-report measure and may be biased due to social desirability issues.

\section{References:}

1. Abouzari-Gazafroodi, K., Najafi, F., Kazemnejad, E., Rahnama, P., \& Montazeri, A. (2015). Demographic and obstetric factors affecting women's sexual functioning during pregnancy. Reproductive Health, 12(1), 1-5. doi: 10.1186/s12978-015-0065-0

2. Acosta, M. V., Llopis, J. M., Gómez-Peresmitré, G., \& Pineda, G. (2005). Evaluación de la conducta alimentaria de riesgo. Estudio transcultural entre dolescentes de España y México. International Journal of Psychology and Psychological Therapy, 5(3), 223-232.

3. Álvarez-Rayón, G., Franco-Paredes, K., López-Aguilar, X., MancillaDíaz, J. M., \& Vázquez-Arévalo, R. (2009). Imagen corporal y trastornos de la conducta alimentaria. Revista de Salud Pública, 11(4), 568-578.

4. Blanco, H., Ornelas, M., Tristán, J. L., Cocca, A., Mayorga-Vega, D., López-Walle, J., \& Viciana, J. (2013). Editor for creating and applying computerise surveys. Procedia Social and Behavioral Sciences, 106, 935-940. doi: 10.1016/j.sbspro.2013.12.105

5. Blanco, J. R. (2016). Factores personales, actividad física y bienestar psicológico. (Tesis doctoral), Universidad Autónoma de Chihuahua, Chihuahua México.

6. Botella, L., Ribas, E., \& Ruiz, J. B. (2009). Evaluación Psicométrica de la Imagen Corporal: Validación de la versión española del multidimensional body self relations questionnaire (MBSRQ). Revista Argentina de Clínica Psicológica, 18(3), 253-264.

7. Brown, F. L., \& Slaughter, V. (2011). Normal body, beautiful body: Discrepant perceptions reveal a pervasive 'thin ideal' from childhood to adulthood. Body Image, 8(2), 119-125. doi: 10.1016/j.bodyim.2011.02.002

8. Brown, T. A., Cash, T. F., \& Mikulka, P. J. (1990). Attitudinal BodyImage Assessment: Factor Analysis of the Body-Self Relations Questionnaire. Journal of Personality Assessment, 55(1), 135-144. doi: 10.1080/00223891.1990.9674053 
9. Cash, T. F., \& Smolak, L. (2012). Understanding Body Images: Historical and Contemporary Perspectives. New York: Guilford Press.

10. Contreras, O. R., Gil, P., García, L. M., Fernández, J. G., \& Pastor, J. C. (2012). Incidencia de un programa de Educación Física en la percepción de la propia imagen corporal. Revista de Educación(357), 281-303. doi: 10.4438/1988-592X-RE-2011-357-061

11. Durán, S., Díaz, V., Record, J., Cordón, K., Encina, C., \& Araya, M. (2014). Diferencias entre índice de masa corporal real y el percibido en mujeres universitarias de Chile, Panamá y Guatemala. Nutrición Clínica y Dietética Hospitalaria, 34(2), 29-36. doi: 10.12873/342duranaguero

12. Englera, P. A., Crowtherb, J. H., Daltonb, G., \& Sanftner, J. L. (2006). Predicting Eating Disorder Group Membership: An Examination and Extension of the Sociocultural Model. Behavior Therapy, 37(1), 6979. doi: 10.1016/j.beth.2005.04.003

13. Gasco, M., Briñol, P., \& Horcajo, J. (2010). Cambio de actitudes hacia la imagen corporal: el efecto de la elaboración sobre la fuerza de las actitudes. Psicothema, 22(1), 71-76.

14. Gómez-Mármol, A., Sánchez-Alcaraz, B. J., \& Mahedero-Navarrete, M. d. P. (2013). Insatisfacción y distorsión de la imagen corporal en adolescentes de doce a diecisiete años de edad. Ágora para la Educación Física y el Deporte, 1(15), 54-63.

15. Gómez-Peresmitré, G. (2014). ¿Los trastornos de la conducta alimentaria tienen género? En G. Gómez-Peresmitré (Ed.), Imagen corporal y orientación sexual. Deseo de un modelo corporal masculino ideal. México: Fenix.

16. Gómez-Peresmitré, G., \& Pineda, G. (2014). Imagen corporal en una muestra de hombres adolescentes. En G. Gómez-Peresmitré (Ed.), Imagen corporal y orientación sexual. Deseo de un modelo corporal masculino ideal. México: Fénix.

17. González-Montero, M., André, A. L., García-Petuya, E., López-Ejeda, N., Mora, A. I., \& Marrodán, M. D. (2010). Asociación entre actividad física y percepción de la imagen corporal en adolescentes madrileños. Nutrición Clínica y Dietética Hospitalaria, 30(3), 4-12.

18. Hernández, R., Fernández, C., \& Baptista, P. (2014). Metodología de la investigación. México: McGraw- Hill.

19. Jáuregui, I., \& Bolaños, P. (2010). Body image and quality of life in a Spanish population. International Journal of General Medicine, 4, 6372. doi: 10.2147/IJGM.S16201

20. Le Breton, D. (2002). Antropología del cuerpo y la modernidad. Buenos Aires: Nueva Visión. 
21. López-Guimera, G., \& Sánchez-Carracedo, D. (2010). Prevención de las alteraciones alimentarias. Fundamentos teóricos y recursos prácticos. Madrid: Pirámide.

22. Marco, J. H., Perpiñá, C., \& Botella, C. (2014). Tratamiento de la imagen corporal en los trastornos alimentarios y cambio clínicamente significativo. Anales de Psicología, 30(2), 422-230. doi: 10.6018/analesps.30.2.151291

23. Mercado, C. (2008). Aplicación del análisis de género a los trastornos de la conducta alimentaria. Revista de Salud, 4(14), 1-14.

24. Muñoz, F., Zueck, M. C., Blanco, J. R., Chávez, A., \& Jasso, J. (2014). Body image perception of Mexican youth: A gender comparison. Education Journal, 3(5), 261-265. doi: 10.11648/j.edu.20140305.11

25. Ochner, C. N., Gray, J. A., \& Brickner, K. (2009). The development and initial validation of a new measure of male body dissatisfaction. Eating Behaviors, 10(4), 197-201. doi: 10.1016/j.eatbeh.2009.06.002

26. Pastor, J. L. (2007). Alteraciones en la autopercepción y procesos de socialización. WANCEULEN E.F. DIGITAL, (3), 1-14. Recuperado de http://rabida.uhu.es/dspace/bitstream/handle/10272/1698/b1534957.p df?sequence $=1$ \&origin=publication_detail website:

27. Platas, S., Gómez-Peresmitré, G., \& León, R. (2014). Imagen corporal, seguimiento de dieta restringida e imc en niños de primaria. En G. Gómez-Peresmitré (Ed.), Imagen corporal y orientación sexual. Deseo de un modelo corporal masculino ideal. México: Fenix.

28. Poulisis, J. (2011). Los nuevos trastornos alimentarios (1 ed.). Buenos Aires, Argentina: Consultorio Paidós.

29. Raich, R. M. (2000). Imagen corporal. Conocer y valorar el propio cuerpo. Madrid: Pirámide.

30. Requena-Pérez, C. M., Martín-Cuadrado, A. M., \& Lago-Marín, B. S. (2015). Imagen corporal, autoestima, motivación y rendimiento en practicantes de danza. Revista de Psicología del Deporte, 24(1), 3744.

31. Rodríguez-Fernández, A., Axpe, I., \& Goñi, A. (2015). Propiedades psicométricas de una versión abreviada del Cuestionario de Autoconcepto Físico (CAF). Actas Españolas de Psiquiatría, 43(4), 125-132.

32. Rodriguez, B., Oudhof, H., Gonzalez-Arratia, N. I., \& UnikelSantoncini, C. (2010). Desarrollo y validación de una escala para medir imagen corporal en mujeres jóvenes. Salud Mental, 33(4), 325332.

33. Salazar, Z. (2008). Adolescencia e imagen corporal en la época de la delgadez. Reflexiones, 87(2), 67-80. 
34. Solano-Pinto, N., \& Cano-Vindel, A. (2010). IMAGEN. Evaluación de la Insatisfacción con la Imagen Corporal. Madrid: TEA.

35. Solano-Pinto, N. y Cano-Vindel, A. (2012). Ansiedad en los trastornos alimentarios: Un estudio comparativo. Psicothema, 24(3), 384-389.

36. Solís, O. B., Blanco, H., Solano-Pinto, N., \& Gastelum, G. (2017). Composición factorial del cuestionario IMAGEN en universitarios mexicanos. Revista de psicología del deporte, 26(Suppl 2), 35-42.

37. Toro, J. (2013). El adolescente ante su cuerpo. Madrid: Pirámide.

38. Trejo, P. M., Castro, D., Facio, A., Mollinedo, F. E., \& Valez, G. (2010). Insatisfacción con la imagen corporal asociada al Índice de Masa Corporal en adolescentes. Revista Cubana de Enfermeria, 26(3), 144-154.

39. Vaquero-Cristóbal, R., Alacid, F., Muyor, J. M., \& López-Miñarro, P. Á. (2013). Imagen corporal; revisión bibliográfica. Nutrición Hospitalaria, 28(1), 27-35. doi: 10.3305/nh.2013.28.1.6016

40. Watson, B., Fuller-Tyszkiewicz, M., Broadbent, J., \& Skouteris, H. (2015). The meaning of body image experiences during the perinatal period: A systematic review of the qualitative literature. Body Image, 14, 102-113. doi: 10.1016/j.bodyim.2015.04.005

41. Wilksch, S., Paxton, S. J., Byrne, S. M., Austin, S. B., McLean, S. A., Thompson, K., Dorairaj, K., \& Wade, T.D. (2015). Prevention Across the Spectrum: a randomized controlled trial of three programs to reduce risk factors for both eating disorders and obesity. Psychological Medicine, 45(9), 1811-1823. doi: 10.1017/S003329171400289X 